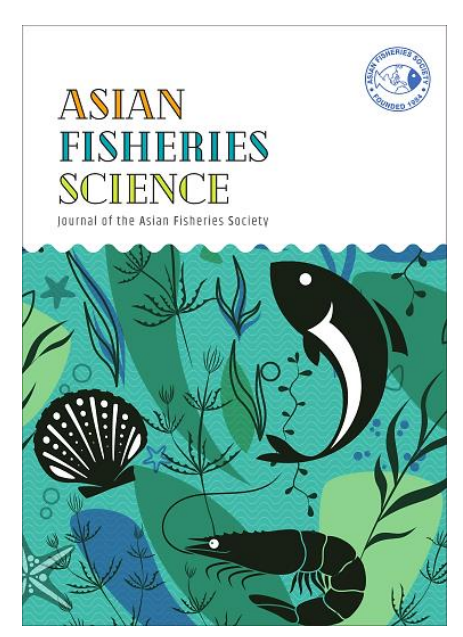

(c) Asian Fisheries Society

Published under a Creative Commons

license

ISSN: 0116-6514

E-ISSN: 2073-3720

https://doi.org/10.33997/j.afs.2021.34.2.001

\section{Substitution of Fishmeal with Black Soldier Fly Hermetia illucens Linnaeus, 1758 Larvae in Finfish Aquaculture - A Review}

\begin{abstract}
MANIYANGAMAGE KASUN CHATHURANGA PRIYADARSHANA*, CHAMINDA NIROSHAN WALPITA, MANOHARAN NAVEENAN, MANJULA PRIYANTHA SUMITH MAGAMAGE, HETTIPALA ARACHCHIGE DARSHANEE RUWANDEEPIKA
\end{abstract}

Department of Livestock Production, Faculty of Agricultural Sciences, Sabaragamuwa University of Sri Lanka,

Belihuloya 70140, Sri Lanka

*E-mail: kasunc@agri.sab.ac.lk |Received: 20/10/2020; Accepted: 03/06/2021

\begin{abstract}
The reliance of aquaculture feed industry on fishmeal has been challenged by ecological, economic, and ethical limitations leading fish nutritionists to look for viable alternatives, and conventional animal-based protein sources showed varying degrees of success in this regard. However, a non-conventional protein source, black soldier fly Hermetia illucens Linnaeus, 1758 larvae (BSFL), received due attention as a focal point in fish nutrition research. Though many studies were conducted on $\mathrm{H}$. illucens as a potential protein source for fish, a comprehensive review is not available. Therefore, this article aims to review the existing literature on the use of BSFL as a fishmeal replacer in aquaculture. The nutrient composition of BSFL varied with the developmental stage and the composition of growing medium. High crude protein levels (40.4-56.2 \%) and high crude fat levels (4.8-24.8 \%) made BSFL suitable for high protein and high energy diet. Early prepupa was the best stage for harvesting, considering its high crude protein content and dry matter yield and less chitin content. Up to $100 \%$ inclusion levels of BSFL meal were tested in a wide range of fish species. Most studies revealed that up to $50 \%$ of fishmeal replacement would be possible without negative effects on the fish. Notable adverse effects were found beyond $50 \%$ of fishmeal replacement, mainly due to high chitin levels in the pupal stage and high crude fat levels. Harvesting BSFL before the pupal stage and defattening made it possible to replace $100 \%$ of fishmeal without adverse effects on fish.
\end{abstract}

Keywords: growth, fish diet, fish farming, fish feed

\section{Introduction}

Aquaculture nutrition has long been plagued by its reliance on fishmeal as a major protein source. Increasing demand for aqua-feeds and the limited supply of fishmeal with its inherited problems of ecological, ethical, technical, and economic roots have rendered it unsustainable for use in aquaculture (Rumsey, 1993; Kudi et al., 2008; Li et al., 2015). With the choice of protein source making a significant impact on the growth and development of the fish, as well as the cost of production (Tacon and Metian, 2008; Asche et al., 2012; Barroso et al., 2014), a viable alternative to replacing fishmeal without compensating its advantages would be a priced finding. Plant-based protein sources gained substantial research interest due to low cost and unlimited availability, yet, had proven incompatibilities due to unbalanced amino acid profiles mismatching with fish requirements and, presence of anti-nutritive factors (Gomes et al., 1995; Francoise and Sadasivam, 2009; Rimoldi et al., 2014; Caimi et al., 2020). Alternatively, animal-based proteins have shown more promise (Francoise and Sadasivam, 2009; Rimoldi et al., 2019), and among them, dipteran larvae meals received due attention. Black soldier fly Hermetia illucens Linnaeus, 1758 is one such dipteran whose larval meals have been well tested as a fishmeal replacer in many studies. With its high protein content and balanced amino acid profile suitable for fish, supported by the fly larvae to be used as a source of bio-degrading wastes (Diener et al., 2011; Huis et al., 2013), BSFL have pushed fish nutrition research into a new dimension. Even with such potential, however, comprehensive reviews of the existing literature on using BSFL as a source of fishmeal replacer in 
aquaculture feeds are so far unavailable. The present review was, therefore, an effort to fill that gap.

\section{Taxonomy and Life Cycle of Hermetia illucens}

Hermetia illucens (Diptera: Stratiomyidae) is an insect commonly known as black soldier fly (BSF), has an external morphology similar to the wasps. BSF has two wings and does not possess any stinging structures (Diclaro II and Kaufman, 2009). Its natural distribution includes Asia, Europe and the southeastern United States. Subsequently, their distribution expanded to other areas and today, they are predominantly found in equatorial tropics (Liu et al., 2017). The life stages of BSF are shown in Figure 1.

The life cycle of the BSF extends from weeks to quality and quantity of the diet (Veldkamp et al., 2012). After successful mating, female deposits clusters of eggs on the edges of containers near waste dumps and decaying organic matter (Tomberlin and Sheppard, 2001). Eggs normally hatch within 4-10 days (Mullen and Durden, 2002). Newly hatched BSFL are creamy white, gradually turning into brownish and becoming completely black during the prepupal stage within two weeks (Gennard, 2012). At the prepupal stage, larvae cease feeding and migrate towards dry and dark places to prepare for the oncoming pupal stage of 14-16 days (Hardouin and Mahoux, 2003).

\section{Nutrient content of black soldier fly larvae}

The composition of the black soldier fly larvae (BSFL) largely depends on the composition of the substrate months, depending on the temperature and the

(Spranghers et al., 2017). The dry matter (DM) content of BSF larvae gradually increases from day-old larvae to the prepupal stage to an average of $35-45 \%$, which remains stable throughout the pupal stage and drops to $20-25 \%$ when the larvae reach the adult stage (Newton et al., 2005; Liu et al., 2017; Gangadhar et al., 2018). The crude protein (CP) content of BSFL exceptionally varies throughout the life cycle and remains around $40 \%$ during the larval stage ( $\mathrm{Li}$ et al., 2015; Gangadhar et al., 2018). Body crude fat (CF) content also fluctuates depending on the nature of the diet consumed (Gangadhar et al., 2018). However, from day-old larvae to prepupal stage, the CF value remains at an average of $24-28 \%$ (Li et al., 2015). A variety of essential amino acids and fatty acids are synthesised in every growth stage and the amounts are much higher in the early larval stages (Li et al., 2015). Significantly higher calcium and phosphorus levels (3000 mg.100 g gand $620 \mathrm{mg} .100 \mathrm{~g}^{-1}$, respectively) are also found in larval stages compared to adults. Furthermore, chitin content gradually increases with age and becomes much higher when it develops to the prepupal stage (Bosch et al., 2014; Maurer et al., 2015). Moreover, other minerals such as sodium, iron and zinc levels are $100 \mathrm{mg}, 200 \mathrm{mg}$ and $60 \mathrm{mg} .100 \mathrm{~g}^{-1}$, respectively. BSFL are also rich in vitamins, especially vitamin E (7 mg.100 g ${ }^{-1}$ )(Liu et al., 2017; Jansen, 2018).

\section{Changes in body composition of BSFL throughout the life cycle}

Owing to drastic changes in life stages during a short period, the body composition of BSFL also varies during each phase. A study by Liu et al. (2017) described the use of commercial broiler chicken feed as a growth substrate for BSFL to show the dynamic changes in their body composition. Percentage CP
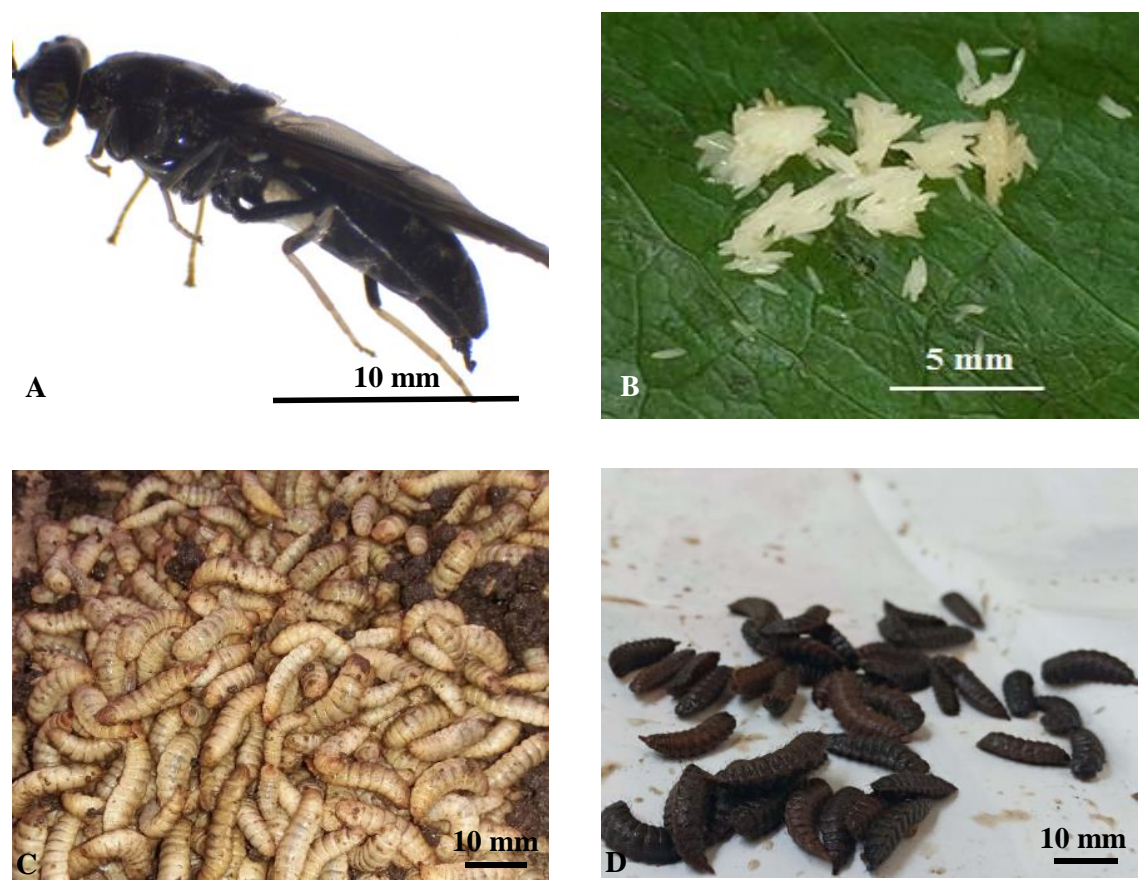

Fig. 1. Life stages of black soldier fly Hermetia illucens, A: Adult; B: Eggs; C: Larvae; D: Pupae. 
levels in BSFL ranged between 38.4 to $56.5 \%$ where the highest levels were in one day old larvae, and the least was in 12 days old larvae (Fig. 2). The CP content of individual larva shows a gradual increasing trend, where the lowest content was in the one-day-old early larval stage $(0.006 \mathrm{mg}$ per larva), and the highest (28.228 mg per larva) was in the early pupa stage. The CP levels decreased at late pupa (25.798 mg) and adult (15.149 mg per individual) stages. Considering percentage CP levels and biomass, it is likely to have the best output at the mature larval stage $\left(14^{\text {th }}\right.$ day of development) and early-prepupa.

Variations in CF content have also been reported during the life cycle. Decreasing CF content from $16 \%$ to $5 \%$ was reported during the development of eggs to one-day-old larvae (Fig. 2). An increase in CF content was observed during certain stages of larval development, followed by a plateauing trend at the late prepupal stage. Increased levels of CF were reported in adult flies. Evidence suggests that mature larval stages and early prepupal stages contain the highest CF contents of $18.091 \mathrm{mg}$ and $18.760 \mathrm{mg}$, respectively (Liu et al., 2017). The decline in CF content was reported during later larval stages. Adult phases showed an increase in CF content, ensuring fulfilment of the energy demand for reproduction of the species.

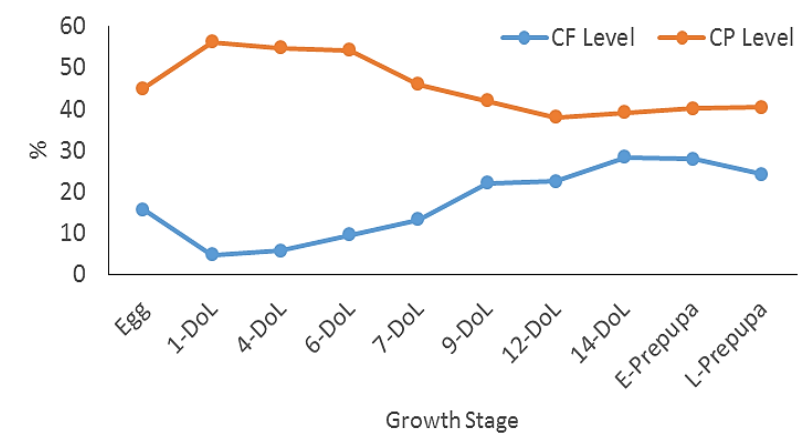

Fig. 2. Changes in crude protein (CP) and crude fat (CF) percentages of Hermetia illucens larvae throughout the life cycle. CP level increased in one-day old larvae. From the $7^{\text {th }}$ day of larval development, a reduction in CP content was observed until $12^{\text {th }}$ day, followed by less variation in the next development stages. A decreasing trend of CF content was reported during early larval development, followed by a steady increase up to $22 \%$ on the $9^{\text {th }}$ day. The value remained around $28 \%$ until late-prepupa stage and reduced to $8 \%$ at early-pupa stage. However, the CF level increased up to $30-32 \%$ during the adult stage. DoL stands for day old larvae. Source: Liu et al. (2017).

The dry biomass increased to a range of $65-70 \mathrm{mg}$ at the early prepupa stage. From the fourth day onwards, there is an increase of biomass along with the larval development, where a rapid increment was observed between day 9 and day 12. Afterwards, a decline in dry biomass was noticed until death.
However, biomass accumulation was about 4000 -fold in 14-16 days.

The early prepupa stage was revealed as one of the critical stages in the life cycle of BSF due to high CP content and dry matter (Spranghers et al., 2017; Gangadhar et al., 2018; Cardinaletti et al., 2019). The cuticle begins to develop beyond the early prepupae stage, and this growth stage was found to be ideal for harvesting and used for the preparation of aquaculture feed.

\section{Effect of growth substrate on the body composition of BSFL}

Several studies were conducted to determine the effect of different growth substrates on the body composition of BSFL. According to Liu et al. (2017), dynamic changes in the nutrient composition were observed in BSF grown in broiler chicken feed. CP content was $38 \%$ in 12-day old larvae. The mean value for CP was at $43 \%$ in the prepupa stage. CF content increased during larval development and was reported to remain at a range of $22-28 \%$. Spranghers et al. (2017) studied the effect of different growth substrates such as chicken feed, vegetable waste and restaurant waste on BSFL body composition. The results showed that CP content was higher in larvae grown on restaurant waste $(43 \%)$ and lowest in vegetable waste (39\%). CF content was highest in restaurant waste and vegetable waste-based growth substrates (36-38\%). However, the chitin content of BSFL was between $5.7 \%$ and $6.7 \%$. According to Jucker et al. (2017), CP content in BSFL grown on fruits, vegetables and the fruit-vegetable mixture was $12-18 \%$. The CF content was reported to be $21 \%$ in larvae grown on the fruit-based substrate and $3 \%$ in larvae grown on vegetables. The ash content of larvae was $4 \%$ in fruit and vegetable-based substrates. Furthermore, Newton et al. (2005) reported that CP content in larvae grown in poultry and swine manure was $43 \%$. However, variations in CF content were reported among substrates (35\% in poultry manure and $27 \%$ in swine manure). The ash content in both fruit-based and vegetable-based substrates was $16 \%$. Accordingly, it was evident that the growth substrate has a direct impact on the proximate composition of BSFL. The selection of growth substrate depends on the purpose of rearing BSFL, such as rearing BSFL on substrates based on restaurant waste, can be beneficial for biodiesel production. Similarly, substrates based on poultry and swine manure can be ideal for harvesting larvae with higher CP content for animal feed production.

\section{Incorporation of BSFL in aquaculture feeds}

Many studies have been conducted on the inclusion of BSFL in finfish aquaculture (Table 1). Different inclusion levels of BSFL have been observed in 


\begin{tabular}{|c|c|c|c|}
\hline Fish species & $\begin{array}{l}\text { BSFL inclusion rate } \\
\text { (fishmeal replacement) }\end{array}$ & Effect & Reference \\
\hline $\begin{array}{l}\text { African catfish } \\
\text { Clarias gariepinus } \\
\text { (Burchell, 1822) } \\
\text { fingerling }\end{array}$ & Meal, up to $30 \%$ & $\begin{array}{l}\text { No negative effects on growth } \\
\text { performances until } 20 \% \\
\text { inclusion }\end{array}$ & Talamuk(2016) \\
\hline $\begin{array}{l}\text { Atlantic salmon } \\
\text { Salmo salar } \\
\text { Linnaeus, } 1758 \\
\text { post-smolt, pre-smolt }\end{array}$ & Meal, up to $100 \%$ & $\begin{array}{l}\text { No negative effects on growth } \\
\text { performances until } 85 \% \\
\text { inclusion. Altered fatty acid } \\
\text { profile and increased dry } \\
\text { matter content }\end{array}$ & $\begin{array}{l}\text { Lock et al. (2016); Belghit et } \\
\text { al. (2018; 2019b; 2019a); Li } \\
\text { et al. (2019); Stenberg et al. } \\
\text { (2019) }\end{array}$ \\
\hline $\begin{array}{l}\text { Barramundi } \\
\text { Lates calcarifer } \\
\text { (Bloch, 1790) } \\
\text { juvenile }\end{array}$ & Meal, up to $100 \%$ & $\begin{array}{l}\text { No negative effects on growth } \\
\text { performances until } 50 \% \\
\text { inclusion. Altered essential } \\
\text { amino acid content }\end{array}$ & Katya et al. (2017) \\
\hline $\begin{array}{l}\text { Blue tilapia } \\
\text { Oreochromis aureus } \\
\text { (Steindachner, 1864) } \\
\text { fingerling }\end{array}$ & $\begin{array}{l}\text { Chopped and frozen larvae, up } \\
\text { to } 100 \%\end{array}$ & $\begin{array}{l}\text { No negative effects on growth } \\
\text { performances until } 100 \% \\
\text { replacement }\end{array}$ & $\begin{array}{l}\text { Bondari and Sheppard } \\
\text { (1981) }\end{array}$ \\
\hline $\begin{array}{l}\text { Channel catfish } \\
\text { Ictalurus punctatus } \\
\text { (Rafinesque, 1818) } \\
\text { broodstock }\end{array}$ & Meal, up to $100 \%$ & $\begin{array}{l}\text { No negative effects on growth } \\
\text { performances until } 100 \% \\
\text { replacement }\end{array}$ & $\begin{array}{l}\text { Bondari and Sheppard } \\
\text { (1981) }\end{array}$ \\
\hline $\begin{array}{l}\text { European seabass } \\
\text { Dicentrarchus labrax } \\
\text { (Linnaeus, 1758) } \\
\text { juvenile }\end{array}$ & Meal, up to $45 \%$ & $\begin{array}{l}\text { No negative effects on growth } \\
\text { performances until } 45 \% \\
\text { inclusion }\end{array}$ & $\begin{array}{l}\text { Sánchez-Muros et al. } \\
\text { (2014); López (2015); } \\
\text { Magalhães et al. (2017); } \\
\text { Abdel-Tawwab et al. (2020) }\end{array}$ \\
\hline $\begin{array}{l}\text { Grouper-hybrid } \\
\text { Epinephelus fuscoguttatus } \\
\text { (Forsskål, 1775) q x } \\
\text { Epinephelus lanceolatus ồ } \\
\text { (Bloch, 1790) } \\
\text { juvenile }\end{array}$ & Meal, up to 30 \% & $\begin{array}{l}\text { No negative effects on growth } \\
\text { performances until } 30 \% \\
\text { inclusion }\end{array}$ & Zulkifli et al. (2019) \\
\hline $\begin{array}{l}\text { Hong Kong catfish } \\
\text { Clarias fuscus } \\
\text { (Lacepède, 1803) } \\
\text { juvenile }\end{array}$ & Meal, up to $100 \%$ & $\begin{array}{l}\text { No negative effects on growth } \\
\text { performances until } 66 \% \\
\text { inclusion }\end{array}$ & Stankus (2013) \\
\hline $\begin{array}{l}\text { Japanese seabass } \\
\text { Lateolabraxjaponicus } \\
\text { (Cuvier, 1828) } \\
\text { juvenile }\end{array}$ & Meal, up to $64 \%$ & $\begin{array}{l}\text { No negative effects on growth } \\
\text { performances until } 64 \% \\
\text { inclusion }\end{array}$ & Wang et al. (2019) \\
\hline $\begin{array}{l}\text { Jian carp } \\
\text { Cyprinus carpio } \\
\text { Linnaeus, } 1758 \\
\text { fry, juvenile }\end{array}$ & Meal, up to $100 \%$ & $\begin{array}{l}\text { No negative effects on growth } \\
\text { performances until } 100 \% \\
\text { replacement. Elevated } \\
\text { saturated fatty acid content }\end{array}$ & $\begin{array}{l}\text { Li et al. (2017); Zhou et al. } \\
\text { (2018) }\end{array}$ \\
\hline $\begin{array}{l}\text { Nile Tilapia } \\
\text { Oreochromis niloticus } \\
\text { (Linnaeus, 1758) } \\
\text { fry, fingerling }\end{array}$ & $\begin{array}{l}\text { Meal and whole larvae (dried), } \\
\text { up to } 100 \%\end{array}$ & $\begin{array}{l}\text { No negative effects on growth } \\
\text { performances until } 50 \% \\
\text { inclusion. Body crude fat } \\
\text { content and saturated fatty } \\
\text { acid contents increased }\end{array}$ & $\begin{array}{l}\text { Rana et al. (2015); Muin et } \\
\text { al. (2017); Teye-Gaga (2017); } \\
\text { Devic et al. (2018) }\end{array}$ \\
\hline
\end{tabular}




\begin{tabular}{|c|c|c|c|}
\hline Fish species & $\begin{array}{l}\text { BSFL inclusion rate } \\
\text { (fishmeal replacement) }\end{array}$ & Effect & Reference \\
\hline $\begin{array}{l}\text { Rainbow trout } \\
\text { Oncorhynchus mykiss } \\
\text { (Walbaum, 1792) } \\
\text { fry, juvenile }\end{array}$ & Meal, up to $75 \%$ & $\begin{array}{l}\text { No negative effects on growth } \\
\text { performances until } 30 \% \\
\text { inclusion }\end{array}$ & $\begin{array}{l}\text { St-Hilaire et al. (2007)i } \\
\text { Sealey et al. (2011); Stamer } \\
\text { et al. (2014); Borgogno et al. } \\
\text { (2017); Renna et al. (2017); } \\
\text { Bruni et al. (2018); Dumas et } \\
\text { al. (2018); Mancini et al. } \\
\text { (2018); Terova et al. (2019); } \\
\text { Cardinaletti et al. (2019); } \\
\text { Huyben et al. (2019); } \\
\text { Józefiak et al. (2019); } \\
\text { Rimoldi et al. (2019) }\end{array}$ \\
\hline $\begin{array}{l}\text { Siberian sturgeon } \\
\text { Acipenser baerii } \\
\text { Brandt, } 1869 \\
\text { juvenile }\end{array}$ & Meal, up to $100 \%$ & $\begin{array}{l}\text { No negative effects on growth } \\
\text { performances until } 25 \% \\
\text { inclusion }\end{array}$ & Caimi et al. (2020) \\
\hline $\begin{array}{l}\text { Turbot } \\
\text { Psetta maxima } \\
\text { (Linnaeus, 1758) } \\
\text { juvenile }\end{array}$ & Meal, up to $76 \%$ & $\begin{array}{l}\text { No negative effects on growth } \\
\text { performances until } 33 \% \\
\text { inclusion }\end{array}$ & Kroeckel et al. (2012) \\
\hline $\begin{array}{l}\text { Yellow catfish } \\
\text { Pelteobagrus fulvidraco } \\
\text { (Richardson, 1846) } \\
\text { juvenile }\end{array}$ & Meal, up to $100 \%$ & $\begin{array}{l}\text { No negative effects on growth } \\
\text { performances until } 25 \% \\
\text { inclusion }\end{array}$ & $\begin{array}{l}\text { Hu et al. (2017); Xiao et al. } \\
\text { (2018) }\end{array}$ \\
\hline $\begin{array}{l}\text { Zebra fish } \\
\text { Danio rerio } \\
\text { (Hamilton, 1822) whole life } \\
\text { cycle }\end{array}$ & Meal, up to $100 \%$ & $\begin{array}{l}\text { No negative effects on growth } \\
\text { performances until } 25 \% \\
\text { inclusion }\end{array}$ & $\begin{array}{l}\text { Vargas et al. (2018); } \\
\text { Zarantoniello et al. (2019) }\end{array}$ \\
\hline
\end{tabular}

studies, with some claiming complete replacement of fishmeal. Such studies have focused on the effect of the BSFL diet in different life stages of finfish species. Most studies demonstrated little or absence of negative effects on the growth of finfish species.

\section{Incorporation of BSFL meal on finfish species with different feeding habits}

Numerous studies were conducted focusing on the growth of omnivorous, carnivorous and herbivorous finfish species to determine the effect of BSFL meal. Growth performance indices were used to investigate the impact of BSFL meal. Such indices include weight gain/daily gain (WG/DG), specific growth rate (SGR), weight gain ratio (WGR), feed conversion ratio (FCR), protein efficiency ratio (PER), protein productive value (PPV), condition factor and Thermal-unit growth coefficient (TGC). Organosomatic indices (OSI) such as gonadosomatic index (GSI), hepatosomatic index (HSI), viscerosomatic index(VSI), spleen index (SI) and kidney index $(\mathrm{KI})$ were used to investigate the effect of BSFL meal.

\section{Effect of BSFL meal on omnivorous finfish species}

A thirteen-week feeding experiment in African catfish
Clarias gariepinus (Burchell, 1822) fingerlings revealed that growth was positively affected with $10 \%$ and 20 $\%$ BSFL diet groups while $30 \%$ incorporation had a negative effect. Moreover, it was clearly mentioned that the poor growth in $30 \%$ incorporation was due to the high-fat content followed by reduced feed intake and digestibility. It is possible to replace fishmeal up to $30 \%$ with BSFL meal without significant alterations in FCR, PER, average DG and SGR (Talamuk, 2016). African catfish are omnivorous and mostly feed on detritus, insects, macrophytes and zooplanktons (Dadebo et al., 2014). The distribution of taste buds, mucous cells and micro ridges on epithelial tissues, papilliform teeth found on upper and lower jaws are several key adaptations for their wider range of food preferences (Gamal et al., 2012). Clarias gariepinus have been grouped under carnivorous finfish species due to adaptations such as the formation of a pyloric stomach with the absence of gastric glands to facilitate an alkaline mediated digestion and $J$-shaped stomach comprised of thick tunica muscularis developed with circular muscles for efficient digestion (Ekele et al., 2014). Such adaptations seem to be advantageous for $C$. gariepinus to utilise BSF larval meal effectively.

According to Rana et al. (2015), mono-sex tilapia Oreochromis niloticus (Linnaeus, 1758) fry was tested 
over 90 days using $25 \%$ and $50 \%$ BSFL meal incorporated diets and dehydrated BSF larvae. Lower FCR levels were reported at $50 \%$ inclusion rate and poor growth with $100 \%$ dehydrated larvae. Poor WG was accompanied by poor digestibility in the presence of chitin associated with BSF larvae. The study of Muin et al. (2017) done by incorporating $25 \%, 50 \%, 75$ $\%$ and $100 \%$ BSFL meal in 0. niloticus fingerlings diets showed similar results with Rana et al. (2015). Fish fed with 50 \% BSFL meal showed the highest SGR and best FCR values. Ideal values of WG and PER were reported at $50 \%$ inclusion rate (Muin et al., 2017). A previous study by Teye-Gaga (2017) indicated the possibility of $75 \%$ BSFL meal incorporation without any adverse effects on SGR, CF and FCR. Although the growth rates of 0 . niloticus increased with the inclusion of BSF meal, $50 \%$ was recommended as the ideal level.

Bondari and Sheppard (1981) conducted a 10-weeks study by incorporating $25 \%, 50 \%, 75 \%$ and $100 \%$ chopped and frozen BSF larvae into the diets of blue tilapia Oreochromis aureus (Steindachner, 1864) fingerlings. This study revealed that feed intake was remarkably reduced at the beginning and gradually increased with time. The study concluded by recommending BSFL meal as a potential feed ingredient that can be used combined with other feeds or as the sole ingredient. As described by Sklan et al. (2004), lipase activity is much higher with animal proteins in blue tilapia. In addition to this, the small intestine of 0 . aureus consists of a series of nested loops, lined with villi that facilitate increased absorption due to larger surface area. Furthermore, the study demonstrated that high protein diets had altered the site of nitrogen absorption. In line with the findings of Bondari and Sheppard (1981), the possibility of $100 \%$ BSFL incorporation was evident with 0. niloticus (Devic et al., 2018). However, lower chitin levels associated with early larval stages of $H$. illucens may be the possible reason.

Li et al. (2017) conducted a study by replacing $25 \%, 50$ $\%, 75 \%$ and $100 \%$ fishmeal for juvenile Jian carp Cyprinus carpio Linnaeus, 1758 for 59 days. The study suggested that $100 \%$ replacement of FM can be done using BSFL meal, without any adverse effects on growth. Cyprinus carpio fry has been tested for $\mathrm{H}$. illucens meal incorporated diets by Li et al. (2017) for 56 days and observed no differences in growth between dietary groups. A study performed by Zhou et al. (2018) also recommended maximum incorporation of $100 \%$ BSFL meal in the diets of $C$. carpio.

The activity of protease enzymes and lipases are much higher in carnivorous finfish followed by omnivorous and herbivorous. However, as revealed by several studies (Furné et al., 2005; Castro et al., 2013; Zhao et al., 2020) the activities of trypsin and lipases in Jian carps were similar to carnivorous species. Furthermore, the study revealed an increase in intestinal fold height with the feeding of earthworms, ensuring efficient nutrient absorption. The enhanced digestive ability of insect-based meals is associated with efficient enzymatic activity and intestinal morphology in C. carpio.

Li et al. (2017) reported that the crude lipid content of Jian carp was lower in a fully defatted BSFL mealbased diet. Moreover, histological examinations confirmed that the accumulation of lipids in the hepatopancreas was also reduced. Furthermore, histological examinations revealed that gut histology was altered with the incorporation of partially defatted BSFL meal. Though partially defatted BSFL meal on rainbow trout Oncorhynchus mykiss (Walbaum, 1792) showed no effect on gut histology (Renna et al., 2017), Li et al. (2017) observed some morphological changes in the anterior intestine of Jian carp fed with $8 \%$ fully defatted BSFL meal. Moreover, the defatted BSFL meal contains less cholesterol than fishmeal, leading to lower cholesterol levels in the blood serum of Jian carp. Furthermore, BSFL meal does not show any undesirable effects on the hepatopancreas and immune system of the Jian carp.

BSFL meal is considered a better alternative to fishmeal in the ornamental fish trade. A feeding study on zebrafish Danio rerio (Hamilton, 1822) with $100 \%$ incorporation rate of BSFL meal revealed favourable results in growth. BSF prepupae incorporated diets showed no significant alterations in standard length, dry weight and SGR compared to $100 \%$ commercial diet (Vargas et al., 2018). A study conducted for the same fish species over 6 months with the incorporation of $25 \%$ and $50 \%$ BSFL meal diets suggested that $25 \%$ was the ideal inclusion rate (Zarantoniello et al., 2019). As demonstrated by Vargas et al. (2018) by molecular markers, the BSF prepupae meal can be used as a complete fishmeal replacer in D. rerio without any harmful effects on growth.

\section{Effect of BSFL meal on carnivorous finfish species}

A study conducted on Atlantic salmon Salmo salar Linnaeus, 1758 revealed that $85 \%$ of BSFL meal diet group does not affect the daily feed intake (FI), FCR, $\mathrm{CF}$ and PER. Although growth indices remained unchanged, the GSI and HSI were higher at $85 \%$ inclusion rate (Belghit et al., 2018). In line with that, a feeding trial on S. salar post-smolt with $33 \%, 66 \%$ and $100 \%$ BSFL meal inclusion rates showed no effect on growth performances (Belghit et al., 2019a). Belghit et al. (2019b) revealed no difference in growth observed in a feeding study conducted over 56 days for the same species. However, a reduction in feed intake was observed at $25 \%$ and $50 \%$ inclusion rates. Moreover, an experiment done by replacing up to 100 $\%$ fishmeal showed no sacrifice in growth for S. salar (Lock et al., 2016). The presence of digestive enzymes in pyloric caeca in Atlantic salmon facilitates better 
digestion of proteins, lipids and carbohydrates ( Løkka and Koppang, 2016). This might be the possible reason for enhanced growth performances with BSF larval meal incorporated diets. Moreover, the meal was prepared with larvae harvested at 13 days of development to avoid maturing of BSFL into prepupae. Belghit et al. (2019a) provided further evidence in favour of BSFL meal in S. salar farming. The authors mentioned that the early larval stage of BSF (around 08 days old) was used to prepare experimental diets, ensuring lower levels of chitin content. According to Kawasaki et al. (2019), chitin content in prepupae meal is twice the larval meal. However, Li et al. (2019) observed increased uptake of fatty acids in Atlantic salmon fed with full fat BSF larval meal. Lock et al. (2016) and Dumas et al. (2018) revealed that lauric acid content is much higher in BSFL meal fed to fish. Moreover, lipid droplet accumulation within the enterocytes, known as "hyper-vacuolisation" is caused mainly due to poor quality protein sources. The hyper-vacuolisation causes lipid mal-absorption, leading to a condition termed floating faeces". The study of Li et al. (2019) revealed that hyper-vacuolisation in proximal intestinal enterocytes were reduced in Atlantic salmon fed with non-defatted BSFL meal.

A feeding experiment for juvenile barramundi Lates calcarifer (Bloch, 1790) over 8 weeks by Katya et al. (2017) described no significant effect on the average WG and SGR among $25 \%, 50 \%$ BSFL incorporated diets and the control diet. The study also reported that WG and SGR were considerably low in $75 \%$ and $100 \%$ larval meal incorporated diets. FCR was reportedly higher in fish fed with $100 \%$ BSFL meal. However, no remarkable difference was observed in the control diet and $25 \%, 50 \%$ and $75 \%$ larval incorporated diets. This study showed that up to $75 \%$ fishmeal replacement is possible without any sacrifice in growth. Due to the carnivorous nature of L. calcarifer, the availability of pyloric caeca with less abundance of secretory glands and the presence of a pyloric sphincter facilitates longer retention of feed for prolonged digestion (Purushothaman et al., 2016).

A study conducted over 62 days on European sea bass Dicentrarchus labrax (Linnaeus, 1758) juveniles showed no adverse effects on growth up to $19.5 \%$ replacement of FM (López, 2015). Incompatible with that, 20 days feeding experiment disclosed no significant difference in growth, FCR and PER with up to $45 \%$ incorporation of BSFL meal. Moreover, a depletion in PER was observed at $45 \%$ BSFL meal incorporation (Magalhães et al., 2017). As described by Abdel-Tawwab et al. (2020), no remarkable differences were seen in growth up to $50 \%$ incorporation of BSFL meal. Since European sea bass juveniles are carnivorous, their protein requirement ranged between $45 \%$ and $50 \%$ (Peres and OlivaTeles, 2006). The higher abundance of taste buds in $D$. labrax may transform themselves into selective feeders (Abbate et al., 2012). Wang et al. (2019) observed a remarkably higher feed intake in juvenile Japanese seabass Lateolabrax japonicus (Cuvier, 1828) fed with defatted BSFL meal incorporated diets over fishmeal and found no adverse effects on growth up to $64 \%$ incorporation.

Caimi et al. (2020) examined up to a $100 \%$ inclusion of fully defatted BSFL meal in Siberian sturgeon Acipenser baerii Brandt, 1869 juvenile diets. However, $100 \%$ BSFL meal incorporated diet was not accepted by the juveniles and only $25 \%$ inclusion rate was found to be ideal.

A 12-week study performed with BSFL meal incorporated diets for juvenile grouper fish Epinephelus fuscoguttatus (Forsskål, 1775) x Epinephelus lanceolatus (Bloch, 1790) suggested $30 \%$ inclusion rate for better SGR, FCR and CF values (Zulkifli et al., 2019). Katya et al. (2017), described the overall growth performances of barramundi $L$. calcarifer juveniles were retarded at inclusion rates above $50 \%$. Even though this species is a carnivore, growth performances were not remarkably higher, because BSF prepupae have been used in the preparation of meal, leading to higher chitin content. Zhang et al., (2014) reported that chitin in diets could lead to poor accessibility of enzymes into substrates and reducing retention time of faecal matter. The results of Magalhães et al. (2017) followed the results of Katya et al. (2017), where European sea bass D. labrax was used as the experimental fish species. Additionally, they reported that cholesterol content was much lower with BSFL meal incorporation. This was mainly due to the presence of chitin, which ensures the presence of chitosan that has the ability to reduce cholesterol. However, as described by Karapanagiotidis et al. (2014) and Talamuk (2016), the nutrient composition was not changed by the inclusion of BSFL meal in gilthead sea bream Sparus aurata Linnaeus, 1758 and C. gariepinus, respectively.

As described by Sealey et al. (2011), no retardations in the growth were observed in carnivorous 0 . mykiss, even at $100 \%$ incorporation rate of BSF prepupae meal. Balancing dietary amino acid, which can be limited at higher chitin content, may lead to such a positive effect on growth. Although contradictory results were reported by Sealey et al. (2011), most of the feeding studies conducted for 0 . mykiss using prepupae meal ended up with retarded growth at inclusion levels above 50 \% (St-Hilaire et al., 2007; Stamer et al., 2014; Cardinaletti et al., 2019). These results were similar to the findings of Kroeckel et al. (2012) and Karapanagiotidis et al. (2014) for carnivorous S. aurata and Psetta maxima (Linnaeus, 1758). According to Sealey et al. (2011), significant growth changes were observed in 0 . mykiss fingerlings reared by feeding BSFL based diet. Weight gain (WG) values were low in $25 \%$ and $50 \%$ incorporated BSFL diets compared to the control diet. However, FCR values of $25 \%$ and $50 \%$ incorporated BSFL diets were closer to 1. Moreover, 
$\mathrm{HSI}$ remained equal for both treatments. The study of Stamer et al. (2014) was an extension of Sealey et al. (2011) with an additional BSFL meal inclusion rate of 75 $\%$. Results showed that the replacement of FM by 75 $\%$ of BSFL was ineffective due to a $15 \%$ body weight loss compared to $0 \%$ inclusion. However, $50 \%$ and 75 $\%$ inclusion levels showed higher HSI values. A 78-day feeding study with $0 \%, 25 \%$ and $50 \%$ FM substitution using partially defatted BSFL meal was examined for juvenile rainbow trout (Renna et al., 2017). WG, SGR, FCR, PER, CF, HSI and VSI does not significantly vary among the treatments. The results reported by Bruni et al. (2018) were based on an extended study of Renna et al. (2017), showing that $\mathrm{HSI}$ and VSI were not affected by the diets and up to $50 \%$. St-Hilaire et al. (2007), described that out of 25 $\%$ and $50 \%$ replacements, the lowest WG were observed in $50 \%$. FCR values were higher than 1 for all treatments, while $50 \%$ incorporation of BSFL diet showed the highest FCR value. A 3-month feeding trial conducted by Dumas et al. (2018) using 6.6 \%, 12.2 $\%$ and $24.6 \%$ BSFL meal incorporation rates revealed that FCR values increased with the inclusion of BSFL meal except for $24.6 \%$. Therefore, the study suggested that up to $12.2 \%$ inclusion rate is possible without any disturbance to the growth. Oncorhynchus mykiss juveniles, fed with $0 \%, 25 \%$ and $50 \%$ BSFL diet groups, showed a gradual decline in SGR and gradual increment in FCR values (Cardinaletti et al., 2019). Moreover, in another study, up to $30 \%$ incorporation of BSFL meal revealed no significant alterations among SGR and FCR. Hence, the FCR values were below one up to $30 \%$ of BSFL meal inclusion is recommended for 0 . mykiss (Terova et al., 2019). However, incorporation of BSF prepupae fullfat meal showed no complications in the growth of juveniles, only up to $20 \%$. This study evidenced that higher fat and chitin levels might lead to poor growth associated with full-fat BSF prepupae meals (Józefiak et al., 2019).

A study conducted for $S$. aurata juveniles concluded BSF prepupae meal as a better alternative for FM due to remarkably higher feed consumption even at $100 \%$ FM replacement (Karapanagiotidis et al., 2014).

A 10-week study conducted for channel catfish Ictalurus punctatus (Rafinesque, 1818) using $25 \%, 50$ $\%, 75 \%$ and $100 \%$ chopped and frozen BSFL incorporated diets showed no significant alterations in weight and length gain. However, length and weight gains were found to vary among male and female fish. The study by Bondari and Sheppard, (1981) was the first to investigate the effect of BSFL on fish growth showing the requirement of further studies on different stages of different fish species. As described by Bailey and Harrison (1948), terrestrial and aquatic insects are prominent dietary sources for the wild populations of I. punctatus. Midges Chironomidae Erichson, 1841 and blackflies Simuliidae Newman, 1834 belong to the most commonly utilised insects in the wild.
A 56-day feeding experiment was performed by replacing $0 \%, 17 \%, 33 \%, 49 \%, 64 \%$ and $76 \%$ of fishmeal in juvenile turbot P. maxima. SGR values were lower in diets of $49 \%$ and above inclusion rates of BSFL. FCR was also notably increased beyond 33 $\%$. Elevated levels of chitin and fat contents were revealed as the possible causes for poor feed intake (Kroeckel et al., 2012). According to Han et al. (1999), poor lipid digestibility and absorption were governed by high chitin contents.

Hu et al. (2017) described a significant reduction in WGR and feed conversion beyond $20 \%$ BSFL meal incorporation in juvenile yellow catfish Pelteobagrus fulvidraco (Richardson, 1846). However, contradictory results were reported by Xiao et al. (2018) for the same species. WGR, SGR and PER were remarkably higher in BSFL diet groups compared to control diets. Lower FCR values were reported in $13 \%, 25 \%, 37 \%$ and 48 $\%$ BSFL diet groups. PPV values were also higher in said diet groups. However, when the incorporation rates of BSFL meal exceeded $68 \%$, growth was adversely affected. In juvenile Hong Kong catfish Clarias fuscus (Lacepède, 1803), 66 \% replacement of fish meal with BSFL meal caused minimum adverse effects on growth (Stankus, 2013).

No studies were conducted to test the effectiveness of BSFL meal on herbivorous fish, highlighting the need to fill this knowledge gap using further experimentation. Also, with only one exception by Zarantoniello et al. (2019), BSFL incorporation into fish feeds is mainly focused on one life stage of selected fish species, not for the whole lifecycle.

In some cases, the ideal level of BSFL inclusion within a species appears to vary according to the study. Vargas et al. (2018) recommended $100 \%$ inclusion in D. rerio diet, while Zarantoniello et al. (2019) suggested $25 \%$ inclusion. St-Hilaire et al. (2007) recommended up to a $25 \%$ inclusion rate for juvenile 0 . mykiss, while $50 \%$ inclusion was recommended by Stamer et al., 2014. Even though these differences in inclusion levels may be justified by the growth stages of the fish species and BSFL, further studies are needed to verify the effective utilisation of BSFL in fish. Changes in gut microflora may also be a possible reason, as described by Huyben et al. (2019). An increased abundance of chitinase secreting Bacillacea was found in the gut of 0 . mykiss fed with BSF meal. It may be interesting to follow these gut microbiological studies and gut histopathology to unravel the utilisation potential of BSFL meal by different fish species.

\section{Effect of BSFL meal incorporated diets on body composition of finfish}

Some studies focused on whether the BSFL inclusion would change the body composition in selected fish species. Increased dry matter content in the muscles of $S$. salar fed with BSFL meal was reported by Belghit 
et al. (2018). This is in contrast with the reduction of dry matter content in $D$. rerio fed with $100 \%$ BSFL meal incorporated diets (Vargas et al., 2018). Dry weight loss in C. carpio (Li et al., 2017), 0. mykiss (StHilaire et al., 2007) and P. fulvidraco (Xiao et al., 2018) was reported after feeding a diet incorporated with full-fat BSFL meal.

Contradicting results were also reported in CP levels of BSFL meal fed fish species. Unaffected CP levels were reported in S. salar (Belghit et al., 2019a) and Jian carp (Li et al., 2017; Zhou et al., 2018), whereas elevated body CP levels were reported in 0. mykiss (Mancini et al., 2018; Stamer et al., 2014) and 0. niloticus (Muin et al., 2017). However, Dumas et al. (2018), reported decrease in body CP levels in 0 . mykiss after feeding them with BSFL meal incorporated diets.

Increased levels of essential amino acids, i.e. arginine, histidine, lysine and methionine, were found in L. calcarifer (Katya et al., 2017) fed with BSFL incorporated diets, while unchanged amino acid profiles were reported in S. salar (Belghit et al., 2019a). However, in Jian carp, amino acid profiles were highly varied with the diet (Li et al., 2017; Zhou et al., 2018).

BSFL inclusion in the diet made a variable degree of effects on CF content of the fish body. Unchanged CF contents in the muscles were reported in S. salar (Belghit et al., 2019a) and Jian carp (Li et al., 2017; Zhou et al., 2018). Increased CF levels were found in 0. niloticus (Muin et al., 2017), whereas a significant reduction in CF was observed in 0. mykiss (Sealey et al., 2011; St - Hilaire et al., 2007), P. maxima (Kroeckel et al., 2012) and P. fulvidraco (Xiao et al., 2018). Affected fat digestibility and low energy intake coupled with elevated chitin content were suggested for the said reduction in CF levels.

A significant increase in eicosapentaenoic acid (EPA) and docosahexaenoic acid (DHA) levels were reported in S. salar fed with BSFL incorporated diet (Belghit et al., 2019a). Another study revealed that SFA content in S. salar was doubled at $85 \%$ BSFL inclusion levels (Belghit et al., 2019b). Findings of Zhou et al. (2018) on C. carpio, Devic et al. (2018) on 0. niloticus, Mancini et al. (2018) on 0. mykiss also suggested that SFA contents remarkably increase with the BSFL meal. Elevated lauric acid levels were also detected in 0 . mykiss fed with BSFL meal incorporated diets (Sealey et al., 2011; Stamer et al., 2014; Renna et al., 2017). However, as described by Lock et al. (2016), n-3/n-6 ratio in $S$. salar muscles was decreased with the inclusion of BSFL meal. Unsaturated fatty acid (UFA) contents were also reduced with high levels of BSFL meal incorporation in $D$. rerio (Zarantoniello et al., 2019). A similar decrease in PUFA levels was also reported by Mancini et al. (2018). These variations in the fatty acid profile and CF contents of the fish fed with BSFL may be governed by the nature of substrate used for BSFL rearing and the fish feeding habits (Ewald, 2019, Ewald et al., 2020).

BSFL meal incorporated diets made no changes in the ash content in S. salar (Belghit et al., 2019a), while the levels increased in 0. mykiss (Stamer et al., 2014). Micronutrients such as selenium contents were reduced and iron and manganese contents increased in S. salar muscles (Belghit et al., 2019a). The presence of high mineral contents in insect meals compared to FM was identified as the potential cause for high ash contents (Hu et al., 2017).

These findings clearly show that the fish meal replacement by BSFL larval meal differently affects the body composition of fish. Since the composition of the BSFL meal itself can depend upon the growth stage of BSFL and the substrate in which they are grown, their CP levels, CF levels, amino acid and fatty acid profiles, levels of chitin and minerals would subsequently alter. Also, due to the adaptations in the digestive systems of fish species under investigation and their growth stage, these changes can be further magnified. Hence, one would expect positive changes in fish body composition by positively altering these factors.

\section{Conclusion}

The increasing cost of fish meal and global concern of sustainability in aquaculture has led to the development of alternative sources of feed for culture organisms. Insect based diets, especially black soldier fly larvae (BSFL) meal, has shown very promising results in aquaculture. Due to high levels of crude protein, BSFL has been proven as a good alternative for fish meal. Though it may be disadvantageous if not balanced in the diet, it's high energy and fat content can act as an additional benefit. A balanced amino acid profile and fatty acid profile, together with high mineral contents, made it further suitable as a dietary component in fish feed. However, as the larva get older, chitin deposition act as a bottleneck for its use. Different inclusion levels of BSFL have shown promising results in a variety of aquaculture species, where up to $100 \%$ replacement is possible without adverse effects. However, in many cases, when levels reach more than $50 \%$, negative effects on growth parameters are seen, probably due to high chitin content, high crude fat content, and inability of fish species and growth stage to utilise insect-based diets. The body composition of BSFL fed fish, in many cases, seem to be positively affected. However, there is a need for future studies to be conducted on several commercially important finfish species to identify the potential of BSFL as a suitable alternative for fishmeal.

\section{Acknowledgements}

The authors hereby acknowledge Dr. D.D. Wickramanayake and Mr. P.P.S.K. Patabandi, 
Department of Livestock Production, Faculty of Agricultural Sciences, Sabaragamuwa University of Sri Lanka for assisting in the research work.

Conflict of interest: The authors declare that they have no conflict of interest.

\section{References}

Abbate, F., Guerrera, M.C., Montalbano, G., De Carlos, F., Suarez, A.A., Ciriaco, E., Germana, A. 2012. Morphology of the European sea bass (Dicentrarchus labrax) tongue. Microscopy Research and Technique 75:643-649. https://doi.org/10.1002/jemt.21105

Abdel-Tawwab, M., Khalii, R.H., Metwally, A.A., Shakweer, M.S., Khallaf, M.A., Abdel-Latif, H.M.R. 2020. Effects of black soldier fly (Hermetia illucens L.) larvae meal on growth performance, organs-somatic indices, body composition, and hemato-biochemical variables of European sea bass, Dicentrarchus labrax. Aquaculture 522:735136. https://doi.org/10.1016/j.aquaculture.2020.735136

Asche, F., Oglend, A., Tveteras, S. 2012. Regime shifts in the fishmeal/soybean meal price ratio. Journal of Agricultural Economics 64:97-111. https://doi.org/10.1111/j.1477-9552.2012 $.00357 . x$

Bailey, R.M., Harrison, J.H.M. 1948. Food habits of the southern channel catfish (Ictalurus lacustris punctatus) in the Des Moines River, lowa 75:110-138. https://doi.org/10.1577/1548-8659(1945)75[110:FHOTSC] 2.0.CO;2

Barroso, F.G., Haro, C., Sánchez-Muros, M., Venegas, E., MartinezSanchez, A., Bañón, C. 2014. The potential of various insect species for use as food for fish. Aquaculture 422-423:193-201. https://doi.org/10.1016/j.aquaculture.2013.12.024

Belghit, I., Liland, N.S., Gjesdal, P., Biancarosa, I., Menchetti, E., Li, Y., Waagbø, R., Krogdahl, Å., Lock, E.-J. 2019a. Black soldier fly larvae meal can replace fishmeal in diets of sea-water phase Atlantic salmon (Salmo salar). Aquaculture 503:609-619. https://doi.org 110.1016/j.aquaculture.2018.12.032

Belghit, I., Liland, N.S., Waagbø, R., Biancarosa, I., Pelusio, N., Li, Y., Krogdahl, A., Lock, E.-J. 2018. Potential of insect-based diets for Atlantic salmon (Salmo salar). Aquaculture 491:72-81. https://doi.org /10.1016/j.aquaculture.2018.03.016

Belghit, I., Waagbø, R., Lock, E.-J., Liland, N.S. 2019b. Insect-based diets high in lauric acid reduce liver lipids in freshwater Atlantic salmon. Aquaculture Nutrition 25:343-357. https://doi.org/10.1111 lanu. 12860

Bondari, K., Sheppard, D.C. 1981. Soldier fly larvae as feed in commercial fish production. Aquaculture 24:103-109. https://doi.org/10.1016 10044-8486(81)90047-8

Borgogno, M., Dinnella, C., laconisi, V., Fusi, R., Scarpaleggia, C., Schiavone, A., Monteleone, E., Gasco, L., Parisi, G. 2017. Inclusion of Hermetia illucens larvae meal on rainbow trout (Oncorhynchus mykiss) feed: effect on sensory profile according to static and dynamic evaluations. Journal of the Science of Food and Agriculture 97:3402-3411. https://doi.org/10.1002/jsfa.8191

Bosch, G., Zhang, S., Oonincx, D.G.A.B., Hendriks, W.H. 2014. Protein quality of insects as potential ingredients for dog and cat foods. Journal of Nutritional Science 3:e29. https://doi.org/10.1017 lins.2014.23

Bruni, L., Pastorelli, R., Viti, C., Gasco, L., Parisi, G. 2018. Characterisation of the intestinal microbial communities of rainbow trout (Oncorhynchus mykiss) fed with Hermetia illucens (black soldier fly) partially defatted larva meal as partial dietary protein source. Aquaculture 487:56-63. https://doi.org/10.1016/j.aquaculture.2018
.01 .006

Caimi, C., Renna, M., Lussiana, C., Bonaldo, A., Gariglio, M., Meneguz, M., Dabbou, S., Schiavone, A., Gai, F., Elia, A.C., Prearo, M., Gasco, L. 2020. First insights on black soldier fly (Hermetia illucens L.) larvae meal dietary administration in Siberian sturgeon (Acipenser baerii Brandt) juveniles. Aquaculture 515:734539. https://doi.org/10.1016 /j.aquaculture.2019.734539

Cardinaletti, G., Randazzo, B., Messina, M., Zarantoniello, M., Giorgini, E., Zimbelli, A., Bruni, L., Parisi, G., Olivotto, I., Tulli, F. 2019. Effects of graded dietary inclusion level of full-fat Hermetia illucens prepupae meal in practical diets for Rainbow trout (Oncorhynchus mykiss). Animals 9:251. https://doi.org/10.3390/ani9050251

Castro, C., Pérez-Jiménez, A., Coutinho, F., Pousão-Ferreira, P., Brandão, T.M., Oliva-Teles, A., Peres, H. 2013. Digestive enzymes of meagre (Argyrosomus regius) and white seabream (Diplodus sargus). Effects of dietary brewer's spent yeast supplementation. Aquaculture 416-417:322-327. https://doi.org/10.1016/j.aquaculture .2013 .09 .042

Dadebo, E., Aemro, D., Tekle-Giorgis, Y. 2014. Food and feeding habits of the African catfish Clarias gariepinus (Burchell, 1822) (Pisces: Clariidae) in Lake Koka, Ethiopia. African Journal of Ecology 52:471478. https://doi.org/10.1111/aje.12146

Devic, E., Leschen, W., Murray, F., Little, D.C. 2018. Growth performance, feed utilisation and body composition of advanced nursing Nile tilapia (Oreochromis niloticus) fed diets containing Black Soldier Fly (Hermetia illucens) larvae meal. Aquaculture Nutrition 24:416-423. https://doi.org/10.1111/anu.12573

Diclaro II, J.W., Kaufman, P.E. 2009. Black soldier fly Hermetia illucens Linnaeus (Insecta: Diptera: Stratiomyidae), EENY-461. Entomology and Nematology Department, Florida Cooperative Extension Service, Institute of Food and Agricultural Sciences, University of Florida, USA, pp.2-3

Diener, S., Zurbrügg, C., Gutiérrez, F.R., Nguyen, D.H., Morel, A., Koottatep, T., Tockner, K. 2011. Black soldier fly larvae for organic waste treatment - prospects and constraints. In: International conference on solid waste management in the developing countries. (eds. Alamgir, M., Bari, Q.H., Rafizul, I.M., Islam, S.M.T., Sarkar, G. Howlader, M.K), pp. 1-8. Khulna, Bangladesh.

Dumas, A., Raggi, T., Barkhouse, J., Lewis, E., Weltzien, E. 2018. The oil fraction and partially defatted meal of black soldier fly larvae (Hermetia illucens) affect differently growth performance, feed efficiency, nutrient deposition, blood glucose and lipid digestibility of rainbow trout (Oncorhynchus mykiss). Aquaculture 492:24-34. https://doi.org/10.1016/j.aquaculture.2018.03.038

Ekele, I., Uchenna, N., Okechukwu, N., Isaiah, A. 2014. The stomach of the adult African catfish (Clarias gariepinus, Siluriformes: Clariidae) in farm conditions: A morphological and mucin histochemistry analysis. Revista de la Facultad de Ciencias Veterinarias 55:4-10.

Ewald, N. 2019. Fatty acid composition of black soldier fly larvae impact of the rearing substrate. MS Thesis, Swedish University of Agricultural Sciences, Sweden, pp. 33-50.

Ewald, N., Vidakovic, A., Langeland, M., Kiessling, A., Sampels, S. \& Lalander, C. 2020. Fatty acid composition of black soldier fly larvae (Hermetia illucens) - Possibilities and limitations for modification through diet. Waste Management 102:40-47. https://doi.org/10.1016 /j.wasman.2019.10.014

Francoise, M., Sadasivam, K. 2009. Protein sources in feed for farmed fish. Cahiers Agricultures 18:103-111. https://doi.org/10.1684 lagr.2009.0279

Furné, M., Hidalgo, M.C., López, A., García-Gallego, M., Morales, A.E., Domezain, A., Domezainé, J., Sanz, A. 2005. Digestive enzyme activities in Adriatic sturgeon Acipenser naccarii and rainbow trout 
Oncorhynchus mykiss. A comparative study. Aquaculture 250:391398. https://doi.org/10.1016/j.aquaculture.2005.05.017

Gamal, A.M., Elsheikh, E.H., Nasr, E.S. 2012. Morphological adaptation of the buccal cavity in relation to feeding habits of the omnivorous fish Clarias gariepinus: A scanning electron microscopic study. The Journal of Basic \& Applied Zoology 65:191-198. https://doi.org /10.1016/j.jobaz.2012.04.002

Gangadhar, B., Anand Kumar, B.S., Raghunath, M.R., Sridhar, N. 2018. Pre-pupae (larvae) of black soldier fly-a potential alternate protein source for aquaculture feeds. Aquaculture Asia 22:11-15.

Gennard, D. 2012. Forensic entomology: An introduction. WileyBlackwell, New Jersey, United States. pp. 73-110.

Gomes, E.F., Rema, P., Kaushik, S.J. 1995. Replacement of fishmeal by plant proteins in diets for rainbow trout (Oncorhynchus mykiss): Effect of the quality of the fishmeal based control diets on digestibility and nutrient balances. Aquaculture 130:177-186. https://doi.org/10.1016/0044-8486(94)00211-6

Han, L.K., Kimura, Y., Okuda, H. 1999. Reduction in fat storage during chitin-chitosan treatment in mice fed a high-fat diet. International Journal of Obesity 23:174-179. https://doi.org/10.1038/sj.ijo.0800806

Hardouin, J., Mahoux, G. 2003. Zootechnie d'insectes-Elevage et utilisation au bénéfice de l'homme et de certains animaux. Bureau pour l'Echange et la Distribution de I'Information sur le Mini-élevage (BEDIM), Gembloux, Belgium. 164 pp. (in French).

Hu, J., Wang, G., Huang, Y., Sun, Y., He, F., Zhao, H., Li, N. 2017. Effects of substitution of fishmeal with black soldier fly (Hermetia illucens) larvae meal, in yellow catfish (Pelteobagrus fulvidraco) diets. The Israeli Journal of Aquaculture - Bamidgeh 69:2-8.

Huis, A., Van Itterbeeck, J., Klunder, H., Mertens, E., Halloran, A., Muir, G., Vantomme, P. 2013. Edible insects future prospects for food and feed security. FA0, Rome. pp. 45-93.

Huyben, D., Vidaković, A., Werner Hallgren, S., Langeland, M. 2019 High-throughput sequencing of gut microbiota in rainbow trout (Oncorhynchus mykiss) fed larval and pre-pupae stages of black soldier fly (Hermetia illucens). Aquaculture 500:485-491. https://doi.org/10.1016/j.aquaculture.2018.10.034

Jansen, Z. 2018. The nutritional potential of black soldier fly (Hermetia illucens) larvae for layer hens. Doctoral Dissertation. Stellenbosch University, South Africa, pp. 20-21.

Józefiak, A., Nogales-Mérida, S., Mikołajczak, Z., Rawski, M., Kierończyk, B., Mazurkiewicz, J. 2019. The utilisation of full-fat insect meal in rainbow trout (Oncorhynchus mykiss) nutrition: The effects on growth performance, intestinal microbiota and gastrointestinal tract histomorphology. Annals of Animal Science 19:747-765. https://doi.org/10.2478/aoas-2019-0020

Jucker, C., Erba, D., Leonardi, M.G., Lupi, D., Savoldelli, S. 2017. Assessment of vegetable and fruit substrates as potential rearing media for Hermetia illucens (Diptera: Stratiomyidae) larvae. Environmental Entomology 46:1415-1423. https://doi.org/10.1093 lee/nvx154

Karapanagiotidis, I.T., Daskalopoulou, E., Vogiatzis, I., Rumbos, C., Mente, E., Athanassiou, C.G. 2014. Substitution of fishmeal by fly Hermetia illucens prepupae meal in the diet of gilthead seabream (Sparus aurata). In: HydroMediT2018 International Congress. pp. 110114. Volos, Greece.

Katya, K., Borsra, M.Z.S., Ganesan, D., Kuppusamy, G., Herriman, M., Salter, A., Ali, S.A. 2017. Efficacy of insect larval meal to replace fishmeal in juvenile barramundi, Lates calcarifer reared in freshwater. International Aquatic Research 9:303-312. https://doi.org/10.1007/s40071-017-0178-x

Kawasaki, K., Hashimoto, Y., Hori, A., Kawasaki, T., Hirayasu, H., Iwase, S., Hashizume, A., Ido, A., Miura, C., Miura, T., Nakamura, S., Seyama,
T., Matsumoto, Y., Kasai, K., Fujitani, Y. 2019. Evaluation of black soldier fly (Hermetia illucens) larvae and pre-pupae raised on household organic waste, as potential ingredients for poultry feed. Animals 9:98. https://doi.org/10.3390/ani9030098

Kroeckel, S., Harjes, A.G.E., Roth, I., Katz, H., Wuertz, S., Susenbeth, A., Schulz, C. 2012. When a turbot catches a fly: Evaluation of a prepupae meal of the Black Soldier Fly (Hermetia illucens) as fishmeal substitute - Growth performance and chitin degradation in juvenile turbot (Psetta maxima). Aquaculture 364-365:345-352. https://doi.org/10.1016/j.aquaculture.2012.08.041

Kudi, T.M., Bako, F.P., Atala, T.K. 2008. Economics of fish production in Kaduna State Nigeria. ARPN Journal of Agricultural and Biological Science 3:17-21.

Li, S., Ji, H., Zhang, B., Zhou, J., Yu, H. 2017. Defatted black soldier fly (Hermetia illucens) larvae meal in diets for juvenile Jian carp (Cyprinus carpio var. Jian): Growth performance, antioxidant enzyme activities, digestive enzyme activities, intestine and hepatopancreas histological structure. Aquaculture 477:62-70. https://doi.org /10.1016/j.aquaculture.2017.04.015

Li, W., Zheng, L., Wang, Y.Y., Zhang, J., Yu, Z., Zhang, Y., Li, O. 2015. Potential biodiesel and biogas production from corncob by anaerobic fermentation and black soldier fly. Bioresource Technology 194:276-282. https://doi.org/10.1016/j.biortech.2015 .06 .112

Li, Y., Kortner, T.M., Chikwati, E.M., Munang'andu, H.M., Lock, E.J., Krogdahl, A. 2019. Gut health and vaccination response in pre-smolt Atlantic salmon (Salmo salar) fed black soldier fly (Hermetia illucens) larvae meal. Fish \& Shellfish Immunology 86:1106-1113. https://doi.org/10.1016/j.fsi.2018.12.057

Liu, X., Chen, X., Wang, H., Yang, Q., ur Rehman, K., Li, W., Cai, M., Li, Q., Mazza, L., Zhang, J., Yu, Z., Zheng, L. 2017. Dynamic changes of nutrient composition throughout the entire life cycle of black soldier fly. PLoS ONE 12:e0182601. https://doi.org/10.1371/journal.pone .0182601

Lock, E.R., Arsiwalla, T., Waagbø, R. 2016. Insect larvae meal as an alternative source of nutrients in the diet of Atlantic salmon (Salmo salar) postsmolt. Aquaculture Nutrition 22:1202-1213. https://doi.org/10.1111/anu.12343

Løkka, G., Koppang, E.0. 2016. Antigen sampling in the fish intestine. Developmental \& Comparative Immunology 64:138-149. https://doi.org/10.1016/j.dci.2016.02.014

López, A.S. 2015. Potential of pre-pupae meal of the Black Soldier Fly (Hermetia illucens) as fishmeal substitute: effect on growth performance and digestibility in European sea bass (Dicentrarchus labrax). MS Thesis. Universitat Politécnica de València, Spain, pp.1525.

Magalhães, R., Sánchez-López, A., Leal, R.S., Martínez-Llorens, S., Oliva-Teles, A., Peres, H. 2017. Black soldier fly (Hermetia illucens) pre-pupae meal as a fishmeal replacement in diets for European seabass (Dicentrarchus labrax). Aquaculture 476:79-85. https://doi.org/10.1016/j.aquaculture.2017.04.021

Mancini, S., Medina, I., laconisi, V., Gai, F., Basto, A., Parisi, G. 2018. Impact of black soldier fly larvae meal on the chemical and nutritional characteristics of rainbow trout fillets. Animal 8: 16721681. https://doi.org/10.1017/S1751731117003421

Maurer, V., Holinger, M., Amsler, Z., Früh, B., Wohlfahrt, J., Stamer, A., Leiber, F. 2015. Replacement of soybean cake by Hermetia illucens meal in diets for layers. Journal of Insects as Food and Feed 2:8390. https://doi.org/10.3920/JIFF2015.0071

Muin, H., Taufek, N.M., Kamarudin, M.S., Razak, S.A. 2017. Growth performance, feed utilisation and body composition of Nile tilapia, Oreochromis niloticus (Linnaeus, 1758) fed with different levels of 
black soldier fly, Hermetia illucens (Linnaeus, 1758) maggot meal diet. Iranian Journal of Fisheries Sciences 16:567-577.

Mullen, G., Durden, L. 2002. Medical and veterinary entomology. Academic Press, Cambridge, Massachusetts, USA, pp. 303-309.

Newton, L., Sheppard, C., Watson, D., Burtle, G., Dove, R. 2005. Using the black soldier fly, Hermetia illucens, as a value-added tool for the management of swine manure. The Animal and Poultry Waste Management Center, North Carolina State University, Raleigh, NC, USA, pp. 9-13.

Peres, H., Oliva-Teles, A. 2006. Effect of the dietary essential to nonessential amino acid ratio on growth, feed utilisation and nitrogen metabolism of European sea bass (Dicentrarchus labrax). Aquaculture 256:395-402. https://doi.org/10.1016/j.aquaculture $\underline{.2006 .02 .010}$

Purushothaman, K., Lau, D., Saju, J.M., Musthaq Sk, S., Lunny, D.P., Vij, S., Orban, L. 2016. Morpho-histological characterisation of the alimentary canal of an important food fish, Asian seabass (Lates calcarifer). PeerJ 4:e2377. https://doi.org/10.7717/peerj.2377

Rana, K.M.S., Salam, M.A., Hashem, S., Islam, M.A. 2015. Development of black soldier fly larvae production technique as an alternate fish feed. International Journal of Research in Fisheries and Aquaculture 5:41-47.

Renna, M., Schiavone, A., Gai, F., Dabbou, S., Lussiana, C., Malfatto, V., Prearo, M., Capucchio, M.T., Biasato, I., Biasibetti, E., De Marco, M., Brugiapaglia, A., Zoccarato, I., Gasco, L. 2017. Evaluation of the suitability of a partially defatted black soldier fly (Hermetia illucens L.) larvae meal as ingredient for rainbow trout (Oncorhynchus mykiss Walbaum) diets. Journal of Animal Science and Biotechnology 8:57. https://doi.org/10.1186/s40104-017-0191-3

Rimoldi, S., Gini, E., lannini, F., Gasco, L., Terova, G. 2019. The effects of dietary insect meal from Hermetia illucens prepupae on autochthonous gut microbiota of rainbow trout (Oncorhynchus mykiss). Animals 9:143. https://doi.org/10.3390/ani9040143

Rumsey, G.L. 1993. Fishmeal and alternate sources of protein in fish feeds update 1993. Fisheries 18(7):14-19. https://doi.org /10.1577/1548-8446(1993)018<0014:fmaaso>2.0.co;2

Sánchez-Muros, M.J., Barroso, F.G., Agugliaro, F.M. 2014. Insect meal as renewable source of food for animal feeding: a review. Journal of Cleaner Production 65:16-27. https://doi.org/10.1016 /j.jclepro.2013.11.068

Sealey, W.M., Gaylord, T.G., Barrows, F.T., Tomberlin, J.K., McGuire, M.A., Ross, C., St-Hilaire, S. 2011. Sensory analysis of rainbow trout, Oncorhynchus mykiss, fed enriched black soldier fly prepupae, Hermetia illucens. Journal of the World Aquaculture Society 42:3445. https://doi.org/10.1111/j.1749-7345.2010.00441.x

Sklan, D., Prag, T., Lupatsch, I. 2004. Structure and function of the small intestine of the tilapia Oreochromis niloticus $x$ Oreochromis aureus (Teleostei, Cichlidae). Aquaculture Research 35:350-357. https://doi.org/10.1111/j.1365-2109.2004.01020.x

Spranghers, T., Ottoboni, M., Klootwijk, C., Ovyn, A., Deboosere, S., Meulenaer, B., Michiels, J., Eeckhout, M., De Clercq, P., De Smet, S. 2017. Nutritional composition of black soldier fly (Hermetia illucens) prepupae reared on different organic waste substrates. Journal of the Science of Food and Agriculture 97:2594-2600. https://doi.org/10.1002/jsfa.8081

St-Hilaire, S., Sheppard, C., Tomberlin, J., Irving, S., Newton, L., McGuire, M., Mosley, E., Hardy, R., Sealey, W. 2007. Fly prepupae as a feedstuff for rainbow trout, Oncorhynchus mykiss. Journal of the World Aquaculture Society 38:59-67. https://doi.org/10.1111/j.17497345.2006.00073.x

Stamer, A., Wessels, S., Neidigk, R., Schwark, G.H. 2014. Black soldier fly (Hermetia illucens) larvae-meal as an example for a new feed ingredients' class in aquaculture diets. In: $4^{\text {th }}$ ISOFAR scientific conference 'Building Organic Bridges', at the Organic World Congress, pp. 1043-1046. Istanbul, Turkey.

Stankus, A. 2013. Integrating biosystems to foster sustainable aquaculture: Using black soldier fly larvae as feed in aquaponic systems. M.Sc. Thesis. Zoology Department, University of Hawai'i Mānoa, pp.55-63.

Stenberg, O., Holen, E., Piemontese, L., Liland, N., Lock, E.-J., Espe, M. Belghit, I. 2019. Effect of dietary replacement of fishmeal with insect meal on in vitro bacterial and viral induced gene response in Atlantic salmon (Salmo salar) head kidney leukocytes. Fish \& Shellfish Immunology 91: 223-232. https://doi.org/10.1016/j.fsi.2019.05.042

Tacon, A.G.J., Metian, M. 2008. Global overview on the use of fishmeal and fish oil in industrially compounded aqua-feeds: Trends and future prospects. Aquaculture 285:146-158. https://doi.org/10.1016 /j.aquaculture.2008.08.015

Talamuk, R. 2016. Comparisons of growth performance of african catfish (Clarias gariepinus Burchell, 1822) fingerlings fed different inclusion levels of black soldier fly (Hermetia illucens) larvae meal diets. M.Sc. Thesis. Stellenbosch University, South Africa, pp. 34-36.

Terova, G., Rimoldi, S., Ascione, C., Gini, E., Ceccotti, C., Gasco, L. 2019. Rainbow trout (Oncorhynchus mykiss) gut microbiota is modulated by insect meal from Hermetia illucens prepupae in the diet. Reviews in Fish Biology and Fisheries 29:465-486. https://doi.org /10.1007/s11160-019-09558-y

Teye-Gaga, C. 2017. Evaluation of larval meal diet of black soldier fly (Hermetia illucens: L. 1758) on fingerlings culture of Nile tilapia (Oreochromis niloticus: L.). M.Phil. Thesis. University of Ghana, Legon, pp. 63-71.

Tomberlin, J., Sheppard, D. 2001. Lekking Behavior of the black soldier fly (Diptera: Stratiomyidae). Florida Entomologist 84:729-730. https://doi.org/10.2307/3496413

Turchini, G.M., Torstensen, B.E., Ng, W.-K. 2009. Fish oil replacement in finfish nutrition. Reviews in Aquaculture 1:10-57. https://doi.org/10.1111/j.1753-5131.2008.01001.x

Vargas, A., Randazzo, B., Riolo, P., Truzzi, C., Gioacchini, G., Giorgini, E., Loreto, N., Ruschioni, S., Zarantoniello, M., Antonucci, M., Polverini, S., Cardinaletti, G., Sabbatini, S., Tulli, F., Olivotto, I. 2018. Rearing zebrafish on black soldier fly (Hermetia illucens): Biometric, histological, spectroscopic, biochemical, and molecular implications. Zebrafish 15:404-419. https://doi.org/10.1089 /zeb.2017.1559

Veldkamp, T., van Duinkerken, G., van Huis, A., Lakemond, C.M.M. Ottevanger, E., Bosch, G., van Boekel, M.A.J.S. 2012. Insects as a sustainable feed ingredient in pig and poultry diets: a feasibility study. Wageningen UR Livestock Research, Wageningen, pp. 3-4.

Wang, G., Peng, K., Hu, J., Yi, C., Chen, X., Wu, H., Huang, Y. 2019. Evaluation of defatted black soldier fly (Hermetia illucens L.) larvae meal as an alternative protein ingredient for juvenile Japanese seabass (Lateolabrax japonicus) diets. Aquaculture 507:144-154 https://doi.org/10.1016/j.aquaculture.2019.04.023

Xiao, X., Jin, P., Zheng, L., Cai, M., Yu, Z., Yu, J., Zhang, J. 2018. Effects of black soldier fly (Hermetia illucens) larvae meal protein as a fishmeal replacement on the growth and immune index of yellow catfish (Pelteobagrus fulvidraco). Aquaculture Research 49:15691577. https://doi.org/10.1111/are.13611

Zarantoniello, M., Randazzo, B., Truzzi, C., Giorgini, E., Marcellucci, C., Vargas-Abundez, J.A., Zimbelli, A., Annibaldi, A., Parisi, G., Tulli, F., Riolo, P., Olivotto, I. 2019. A six-months study on Black Soldier Fly (Hermetia illucens) based diets in zebrafish. Scientific Reports 9:8598. https://doi.org/10.1038/s41598-019-45172-5

Zhang, J.B., Zheng, L.Y., Jin, P., Zhang, D.N., Yu, Z.N. 2014. Fishmeal 
substituted by production of chicken manure conversion with microorganisms and black soldier fly. In: Insects to feed the world, The Netherlands, 14-17 May 2014. 153 pp.

Zhao, Y., Zhang, T.R., Li, O., Feng, L., Liu, Y., Jiang, W.D., Wu, P., Zhao, J., Zhou, X.O., Jiang, J. 2020. Effect of dietary L-glutamate levels on growth, digestive and absorptive capability, and intestinal physical barrier function in Jian carp (Cyprinus carpio var. Jian). Animal Nutrition 6:198-209. https://doi.org/10.1016/j.aninu.2020.02.003

Zhou, J.S., Liu, S.S., Ji, H., Yu, H.B. 2018. Effect of replacing dietary fishmeal with black soldier fly larvae meal on growth and fatty acid composition of Jian carp (Cyprinus carpio var. Jian). Aquaculture Nutrition 24:424-433. https://doi.org/10.1111/anu.12574

Zulkifli, M.N.F.N., Yong, A.S.K., Kawamura, G., LeongSeng, L., Senoo, S. Devic, E., Mustafa, S., Shapawi, R. 2019. Apparent digestibility coefficient of black soldier fly (Hermetia illucens) larvae in formulated diets for hybrid grouper (Epinephelus fuscoguttatus $\circ \mathrm{x}$ Epinephelus lanceolatus §). AACL Bioflux 12:513-522. 